\title{
Institutional change of accounting systems: The adoption of a regime of adapted International Financial Reporting Standards in Portugal
}

\section{Marta Silva Gueerreiro, Lúcia Lima Rodrigues, Russell Craig}

\begin{abstract}
We combine Dillard et al.'s (2004) institutional change model with institutional entrepreneurship theory to analyse the introduction of a mandatory national accounting system in Portugal in 2010. We focus on the changes of legitimation criteria and accounting practices that were associated with the accounting standard for small and medium sized entities. Our results enhance understanding of the change processes involved in moving from national to international accounting standards. They reveal how the evolving socio-economic and political context, and the positioning of social actors, enabled entrepreneurial action by the Portuguese accounting standards setting body. Generally, institutional entrepreneurship was enabled by regulatory changes within the EU that encouraged the use of IFRS; and by the embeddedness of central actors in multiple fields. Implementation of the new accounting system was facilitated by actions that involved taking political opportunity, mobilizing important allies, and accommodating the interests of major protagonists. We provide expanded explanations of the Dillard et al. (2004) model with respect to the possibility of an earlier inversion of the cascading institutionalization process. Specifically, we contend that agents at the organizational field level counteracted the institutionalization process before it reached the organizational level. This explanation helps to develop better understanding of the role of national professional accounting associations and business associations in shaping criteria established at the political and economic level. At the organizational level, we provide insights to the reasons why some Portuguese

Key words: International accounting standards; institutionalization; Dillard: accountants maintained the previous accounting system's representational schema and Portugal; accounting change. accounting practices.
\end{abstract}




\section{Introduction}

In 2010, the code-law based accounting system in Portugal that had been applied to unlisted companies was replaced by the non-code law based Sistema de Normalização Contabilística (Accounting Standardization System) [hereafter referred to as $\mathrm{SNC}$. The SNC was inspired by accounting standards issued by the International Accounting Standards Board [IASB]. The SNC included one standard intended for adoption by small and medium-sized entities [SMEs]. Introduction of the SNC prompted important institutional changes in Portuguese accounting. These included the de-institutionalization of previous accounting criteria and practices that had been based on code-law traditions; the establishment of new legitimating criteria; and the embedding of new accounting practices.

The study we report here deploys the recursive model of institutional change proposed by Dillard et al. (2004) to better understand the dynamics and institutional consequences of Portugal's adoption of the SNC. [Hereafter, we refer to this model simply as the Dillard et al. model]. We combine the Dillard et al. model with institutional entrepreneurship theory to highlight the role of endogenous agents in transforming and implementing institutional change (Battilana et al., 2009; DiMaggio, 1988; Greenwood and Suddaby, 2006; Hardy and Maguire, 2008). In particular, we aim to enhance understanding of how various actors collaborated to enable change and to promote the gradual transformation of meanings and criteria in the accounting field. We highlight how institutional entrepreneurship emerged within the Portuguese societal context, and we reveal the processes by which accounting change was implemented. We are motivated by the call of Battilana et al. (2009: 96) to 'understand better how actors can initiate and implement change.'

The theoretical framework of the Dillard et al. model, when combined with institutional entrepreneurship theory, provides an appropriate lens for in-depth analysis of the change processes that occurred in Portuguese accounting. The Dillard et al. model has been applied in several prior studies of institutional changes affecting accounting (Hopper and Major, 2007; Tsamenyi et al., 2006; Cruz et al., 2009) - and specifically in studies relating to the adoption of IFRS (Irvine, 2008; Mir and Rahaman, 2005). Irvine (2008), for example, applied the Dillard et al. model to study the adoption of IFRS in the United Arab Emirates. She concluded that the adoption of IFRS in that country resulted from institutional pressures exerted variously by the World Bank, multi-national corporations, Big 4 accounting firms, and international trading partner 
relationships. Although her study did not analyze the implementation and embedding of new accounting practices, it expressed concerns about the suitability of mandating a single regulatory regime (IFRS) in countries with distinctly different cultural, economic and social environments. Similarly, Mir and Rahaman (2005) used an institutional framework to analyze the adoption of IFRS in Bangladesh. They reported that the lack of a coordinated structure to promote communication among interested parties impaired the process of institutionalizing IFRS.

These preceding studies, unlike the study reported here, have not explored fully the effects of adopting IFRS on the institutional dynamics that flow between the economic and political level, the accounting organizational field level, and the organization level (that is, of accountants). In contrast, we explore the repercussions of adoption for signification, legitimation and domination structures - at each of these three levels.

The following paper contributes to institutional theory in three main ways. First, it adds to the scarce volume of literature that uses institutional theory to analyse the adoption of IFRS by nation states. The in-depth study we present of the implementation of the new IFRS-based Portuguese accounting system [SNC], highlights the difficulties in changing legitimating criteria and accounting practices to achieve de facto application of an accounting standard for SMEs. Our review of the progress of implementing an adapted IFRS accounting system (that is, SNC) at a national level (in Portugal) should be relevant to other countries that are making similar changes to their accounting systems (e.g. Brazil, China, Japan, Mexico, and Turkey).

Second, by combining the Dillard et al. model with institutional entrepreneurship theory, we reinforce an embedded view of institutional entrepreneurs and agency. In particular, our analysis of the processes of change enhances knowledge of the reasons, ways, and means used by actors at the centre of a highly institutionalized field (and privileged by existing institutional arrangements) to enact divergent change in a national accounting system (Lockett et al., 2012; Greenwood and Suddaby, 2006; Battilana et al., 2009). This novel combination extends the Dillard et al. model by fostering understanding of the ways and means by which reflexive, knowledgeable agents act to effect change.

Third, this paper provides useful insights to the reasons why the organizational field is an interactive part of the societal system. In the context of accounting standardsetting, we reveal how actions of agents at the organizational field level can counteract 
the institutionalization process before it reaches the organization level. Further, we show how institutional representativeness explains why pressures can move upwards and downwards in the societal system.

We have two major reasons for focusing on the accounting practices of SMEs at the organization level. First, SMEs have a well known dominant presence in most countries. There are concerns about the relevance of IFRS (or standards based on IFRS) for them (Alp and Ustundag, 2009). In 2009, the IASB finished a five-year development of a special accounting standard for SMEs. In Portugal, 99.5 per cent of companies are classified as SMEs (INE, 2008). Despite the prominence of this type of company in the global economy (they are estimated to compose 95 per cent of all companies globally), ${ }^{1}$ the way SMEs engage with special standards developed for them has seldom been investigated (Alp and Ustundag, 2009; Quagli and Paoloni, 2012; Schutte and Buys, 2011). Our present study seems timely because of its potential to facilitate understanding of the effect of the institutionalization processes on the adoption of the SNC standard for SMEs.

Second, we are mindful that the benefits of adopting any new accounting system should ideally outweigh the costs. Several studies have confirmed that the advantages of adopting IFRS are related to size, and that there are greater levels of acceptance of IFRS by larger companies (e.g. Cuijpers and Buijink, 2005; Dumontier and Raffournier, 1998; Francis et al., 2008). The balance between costs and benefits is an especially important issue for SMEs. Many SMEs feel forced to adopt a set of accounting standards that are oriented more to the needs of capital markets and big capital providers than to them (Alp and Ustundag, 2009). The IASB's standard for SMEs is less complex, requires fewer disclosures, and is revised less frequently and more sparingly than IFRS. Nonetheless, to meet the specific needs of SMEs, it is important to know the extent to which the incorporation of a SME accounting standard into a new accounting system would suit smaller companies.

Our empirical data are sourced from 18 interviews conducted by the first and second authors with actors in the Portuguese social system in the accounting field: at the political level, organizational field level and organization level. Where possible, the factual content of interview data is corroborated through triangulation with information drawn from archival sources.

\footnotetext{
${ }^{1}$ See http://www.ifrs.org/IFRS+for+SMEs/IFRS+for+SMEs.htm, accessed on 16 August, 2012.
} 
The next two sections present the theoretical framework and the institutional and accounting context of Portugal, respectively. The sections that then follow present research methods, results, discussion and conclusions.

\section{Theoretical framework}

Early formulations of institutional theory supported the view that the formal structure of organizations was influenced strongly by widely accepted rationalized myths of appropriate conduct (Meyer and Rowan, 1977). A limitation of institutional theory is its strong emphasis on the organizational field level. This emphasis arises from belief that institutional pressures exerted by competitors, the state or the professions operate from the organizational field (DiMaggio and Powell, 1983). However, to fully understand institutional change we must consider the links between practices at the organizational level and the organizational field level; the influence of higher social, political and economic levels on the organizational context; and the role of influential actors (Dillard et al., 2004). This is consistent with contention that '[c]hange processes are best examined by designs that incorporate multiple levels of analysis. Social actions and structures exist in a dualistic relation, constraining and empowering the other' (Scott, 2001: 203).

The Dillard et al. (2004) framework draws on institutional theory, Weberian notions of social context (Weber, 1968), and a dynamic structuration of social systems that incorporates change into the institutionalization process (Giddens 1976, 1979, 1984). This framework regards institutionalization to be a process that recognizes the political nature of institutional change, and incorporates the relative power of organized interests. The Dillard et al. model represents a continual and dynamic process of institutionalization that proceeds in a recursive cascade through three levels of the social environment - economic and political level, organizational field level, and organizational level. The higher level represents the societal level, where political and economic systems establish general, taken-for-granted norms or criteria $\left(\mathrm{C}_{\mathrm{PE}}\right)$ that are disseminated in society and in the organizational field. The prevailing systems of society and powerful coalitions influence the enactment of these norms, criteria and practices. At the organizational field level, the norms, criteria and practices established at the economic and political level $\left(\mathrm{C}_{\mathrm{PE}}\right)$ are translated into legitimacy criteria $\left(\mathrm{C}_{\mathrm{OF}}\right)$ to evaluate whether action in the organizational field is legitimate. The $\mathrm{C}_{\mathrm{OF}}$ are translated into operating practices $\left(\mathrm{P}_{\mathrm{OF}}\right)$ to provide the legitimating and regulating base for action 
at the organizational level. The organizational field includes industry groups and professional and trade associations.

At the organizational level, organizations can be innovators if they develop new practices within the parameters set by practices $\left(\mathrm{P}_{\mathrm{OF}}\right)$ adopted at the organizational field level. They can be late adopters if they adopt the practices of innovators, even if only ceremonially. Innovative practices can move laterally or vertically. They can modify legitimate practices and criteria in the organizational field by reinforcing, revising or eliminating them. New practices (P'OF) (perceived as 'better practices') are adopted by other organizations within the same organizational field. They become expected (or institutionalized) practices. The new legitimate practices $\left(\mathrm{P}^{\prime}{ }_{\mathrm{OF}}\right)$ and criteria $\left(\mathrm{C}^{\prime}{ }_{\mathrm{OF}}\right)$ at the organizational field level influence the broader macro-level economic and political environment. Hence, they affect symbolic sense-making criteria $\left(\mathrm{C}^{\prime} \mathrm{PE}\right)$ by reinforcing, modifying or eliminating existing norms and practices.

In the Dillard et al. framework, the theoretical context of the institutionalization process incorporates structuration theory. Giddens (1976, 1979, 1984) argues that institutionalized features of social systems have structural properties; and that social forces stabilize relationships across time and space. Accordingly, structure is conceived to be rules and resources that are implicated recursively in social reproduction. Specifically, Giddens contends there are three kinds of structure in a social system. The first type of structure is signification or symbolic representation. This helps to ascribe meaning to social behavior through organized webs of language (such as semantic codes, interpretive schemes and discursive practices) consciously, subconsciously, or unconsciously. The second type of structure is legitimation. This consists of norms, values, laws and regulations that provide meaning and legitimating criteria to evaluate organizational actions. The third type of structure is domination. This is associated with the production of power that arises from the control of human and material resources. ${ }^{2}$

Changes in these three types of social structure are the consequence of reflexive, knowledgeable human action - something which is enabled and simultaneously constrained by the existing structures. According to Dillard et al. (2004: 521) "[i]nstitutions can be seen as manifestations of mutually reinforcing signification (representations) and legitimating structures (values and norms).. reflected and sustained over time by the allocation and accumulation of resources associated with

\footnotetext{
${ }^{2}$ Signification, legitimation and dominations structures coincide with key features of Weber's axes of tension - representation, rationalization and power (Dillard et al., 2004).
} 
their enactment by agents.' Recursive interaction between rules and resources supports and mutually reinforces the implementation and embedding of institutional practices. The loss of either rules or resources is conducive to de-institutionalization, such that eventually symbolic representations or values without resource allocation are discarded.

The institutionalization process allocates resources based on accepted rules, and this then reinforces extant structures. This process involves inverting the cascade as the innovative practices taken by knowledgeable, reflexive agents within organizations, rise through the three levels. Accordingly, the Dillard et al. model represents a recursive process in which changes can move upwards and downwards in response to taken-forgranted norms, criteria, values and beliefs (that are revised continually at all levels).

For Dillard et al. (2004: 535) 'the duality of structure is the fundamental change process.' Action by human agents is the primary mechanism for changing structural elements (signification, legitimation and domination) in each of the three levels of social systems. Thus, the further understanding we provide of why and how actors are more likely to identify and respond to opportunities to enact institutional change will contribute to the development of a more comprehensive appreciation of the Dillard et al. model. This will be facilitated by the integration of insights from institutional entrepreneurship theory into assessment of the model. Both the Dillard et al. model and institutional entrepreneurship theory attend to interests and agency. However, institutional entrepreneurship extends the scope of analysis in three ways: to include the characterization of actors who assume the role of institutional entrepreneurs; to identify the field conditions that create opportunities for change; and to explain the role of interpretative struggles and intervention strategies in changing a field (Hardy and Maguire, 2008). The institutional entrepreneurship branch of institutional theory explores endogenous explanations of institutional change - something which is particularly useful in extending the explanatory power of the Dillard et al. model. Thus, the integration we make helps to reveal how change can be enacted and initiated by human action, whilst still proceeding in a recursive cascade within the societal context.

Institutional entrepreneurs have been defined as organized actors who have interests in particular institutional arrangements and who leverage resources to create new institutions or transform existing ones (DiMaggio, 1988; Maguire et al., 2004). Institutional entrepreneurship requires actors to replace existing practices with new ones, and to then ensure that these practices are adopted widely and taken-for-granted by other actors in a field (Hardy and Maguire, 2008). Battilana et al. (2009) refined this 
definition by specifying two conditions that actors must fulfill to be regarded as institutional entrepreneurs: first, they must initiate divergent changes that break with institutionalized templates and institutional logics within a given context; and second, they must mobilize resources to implement these changes.

According to Hardy and Maguire (2008), institutional entrepreneurship literature promotes two primordial approaches to understand how institutional change commences. The first approach focuses on the way in which fields create a limited number of subject positions or social positions that enable actors to be institutional entrepreneurs. The second approach focuses explicitly on the special characteristics, qualities and abilities that distinguish institutional entrepreneurs from others in a field (Hardy and Maguire, 2008). Consistently, Battilana et al. (2009) developed a model of the process of institutional entrepreneurship that specifies the enabling conditions for institutional entrepreneurship, and the process of implementing divergent change. They identified two types of enabling conditions. First, are the field-level conditions, such as the degree of heterogeneity and institutionalization of the organizational field; and the jolts, crises or regulatory changes that disturb the field-level consensus. Second, are the actors' social positions - something that affects their perception of a field and their access to resources. Implementation of divergent change implicates three activities: developing a shared vision of the need for change; mobilizing people to support and accept new routines; and motivating others to achieve and sustain change.

A limitation of the Dillard et al. model is that it conceptualizes innovators versus late adopters at the organizational field level based on a unitary view of organizations. Hooper and Major (2007) proposed a different approach to diffusion processes at the organizational level. They replaced the two-stage process (innovators versus late adopters) by a process in which organizational field practices $\left(\mathrm{P}_{\mathrm{OF}}\right)$ were translated into working practices $(\mathrm{P})$, and were enacted subsequently, at the intra-organizational level. This translation assumes that ideas and practices are interpreted and reformulated during the process of adoption (Greenwood et al., 2008). Accordingly, if organizational actors experience institutional contradictions during this enactment (such as inconsistencies among, and within, established social arrangements), the consciousness of actors is reshaped; and resistance to imposed institutionalized practices should be expected. This conceptualization is informed by Seo and Creed's (2002) four sources of institutional contradictions: 
1) inefficiency produced by conforming to institutional arrangements that conflict with technical activities, notwithstanding the possibility of loose coupling;

2) poor adaptation to external environments because institutional arrangements make organizations less adaptable over the long run, given psychological resistance to change and economic interdependencies;

3) multiple and contradictory interconnected institutional arrangements and prescriptions organizations cannot totally conform with; and

4) misalignment between social arrangements, such as those that are likely to reflect the ideas and goals of more powerful constituents and the interests of diverse actors who enact, inhabit and reproduce those social arrangements.

These contradictions prompt change in the collective consciousness (or praxis) of actors. They provide alternative logics of action and resources that are used in the process of institutional change.

\section{The Portuguese accounting system and institutional setting}

In Portugal, 99.5 per cent of all firms are SMEs and 97.8 per cent are small and/or micro companies. ${ }^{3}$ SMEs employ about three quarters of the active population and are responsible for 60 per cent of national turnover. Almost all Portuguese SMEs trade in Portugal exclusively - only about 10 per cent export their products (INE, 2008). Financial institutions are the main providers of capital for SMEs. In part, this is because the low importance of capital markets in the Portuguese financial system (Ferreira et al., 2007). In September 2010, only 52 companies were listed on the Portuguese Stock Exchange (Euronext, 2010). Because Portuguese tax authorities and banks are the main users of accounting information, and because there is a small stock market, the low level of concern in Portugal for investors' needs is unsurprising. There is greater concern in Portugal with issues of tax determination and creditor protection. This leads to more prudent and conservative accounting (Ferreira et al., 2007; Ferreira, 1998).

Before the SNC was adopted, the Portuguese accounting system was classified in the Continental cluster of code-law based countries in which accounting was regulated in detail (Mueller et al., 1997; Nobes and Parker, 2004). European countries classified similarly include Belgium, France, Greece and Spain. The Portuguese accounting

\footnotetext{
3 Portuguese Decree-law 372/2007 (6 November) and the European Union's Recommendation 2003/361/CE define SMEs to be companies that fall within one of the three following limits: total assets less than $€ 43$ million; total sales and other income less than $€ 50$ million; or number of employees less than 250. Small companies have less than $€ 10$ million of total assets or total income, and 50 employees; and micro companies have less than $€ 2$ million of total assets or total income, and 10 employees.
} 
system's formative structure is based on the Roman Code. As such, accounting and financial reporting rules are specified and prescribed in law, and are detailed in an Accounting Plan (Ferreira, 1998). Regulation has been developed by way of mercantile legislation (Commercial Code and Companies Law); tax legislation (Tax Code and tax regulations); and accounting legislation (Official Accounting Plan and Accounting Standards).

The first Portuguese Official Accounting Plan (Plano Oficial de Contabilidade POC) was established in 1977 (Decree-law 47/77) - the year the Portuguese accounting standards setter, the Comissão de Normalização Contabilística (CNC - Accounting Standards Board), was established. The CNC comprised a president, a general council, and an executive committee. Members were drawn from the accounting profession, audit profession, users of financial statements (including government departments), and higher education institutions. The Portuguese model of accounting regulation was inspired by the French model. Thus, the standard-setting body, the CNC (which was attached administratively and financially to the Ministry of Finance) was empowered to develop accounting standards that were issued as decrees or decree-laws by the Portuguese Government (Ferreira, 1998). As a consequence, pronouncements by the accounting profession had no formal status. The only source of financial accounting standards was the written law.

Since 1986, the Portuguese accounting system has had to comply with accounting directives of the EU. Additionally, to deal with the insufficiencies of the POC in addressing international financial and accounting developments, the CNC issued several accounting standards inspired by IFRS. As these IFRS-inspired standards came into force, French influence began to wane (Ferreira, 1998). However, de facto harmonization did not occur fully, for several reasons. First, legally the POC was required to prevail over these standards. This encouraged Portuguese accountants to continue to use the POC. Second, only a small number of IAS was adopted; and third, most of these IFRS-inspired standards were only one or two pages long. Fontes et al. (2005) concluded that in 2002 Portuguese standards exhibited a 50\% similarity in terms of accounting treatments and strength of accounting methods with IFRS. The level of disclosure in POC standards was also very low. Thus, Portuguese accounting practices remained oriented towards legal compliance.

Historically, the profession of accountant in Portugal has been separated from the profession of auditor. Two distinct bodies officially represent Portuguese accountants 
and Portuguese auditors, despite the possible overlap in membership. The practice of accounting, and the right to use the title of official accountant, is restricted to the members of the Ordem dos Técnicos Oficiais de Contas (OTOC - Order of Official Accountants). OTOC members contract with their clients to maintain accounting records and prepare financial statements. By law, the annual accounts and tax returns of all companies must be signed by an accountant. OTOC is under the jurisdiction of the Ministry of Finance.

The auditing profession consists of official auditors who are registered in the Ordem dos Revisores Oficiais de Contas (OROC - Order of Official Auditors). This officially recognized body is under the jurisdiction of the Ministry of Justice. The obligation to be audited is compulsory for joint stock companies, limited companies that exceed specified size limits, ${ }^{4}$ financial institutions and insurance companies. OROC and OTOC are represented on the $\mathrm{CNC}$, thereby allowing their participation in the development of accounting standards.

The SNC came into force through Decree-law 158/2009 (13 July), with mandatory effect from 1 January, 2010. Listed companies are required to apply IFRS in individual accounts and in consolidated financial statements. Unlisted companies which prepare consolidated financial statements can opt to adopt IFRS in legally audited consolidated and individual accounts for a minimum period of three years. Unlisted companies not preparing consolidated financial statements are required to apply the set of 28 SNC standards, Normas Contabilísticas de Relato Financeiro (NCRF - Financial Reporting Accounting Standards). These are similar to IFRS. ${ }^{5}$ Companies under the particular limits established by the government can apply a single standard, Norma Contabilística de Relato Financeiro - Pequenas Empresas (NCRF-PE - Financial Reporting Accounting Standard - Small Entities), based on the IASB's accounting standard for SMEs. Nonetheless, if financial statements of the latter group of companies are audited legally, the set of 28 standards is to be applied. At each level, if an issue is not addressed, it is possible to use the accounting treatment in the more complete system - that is, if companies use the NCRF-PE and the accounting treatment for a

\footnotetext{
${ }^{4}$ Total assets $€ 1,500,000$; total sales and other income $€ 3,000,000$; and number of employees 50 .

5 There are two exceptions. The accounting standard for financial instruments was simplified considerably (such that companies can use IASB standards when the SNC standard on financial instruments does not regulate a particular subject). Another exception is the financial accounting reporting standard 26 "Environmental Matters" (based on a European Commission recommendation dated 30 May, 2001).
} 
specific accounting problem is not regulated by it, it can use the 28 standards. As well, if companies use the 28 standards, they can use IAS/IFRS, in omission cases.

The final version of the SNC contains a conceptual framework, 28 accounting standards (NCRF), two interpretative standards, and a specific accounting standard for SMEs (NCRF-PE). All standards are similar to the EU translations of endorsed standards issued by the IASB. The SNC also contains model financial statements and a chart of accounts. The new SNC accounting model differs from the POC in several significant ways:

1) It has a conceptual framework that sets the theoretical concepts underlying all accounting standards. The previous accounting system based on the POC did not have a conceptual framework.

2) It organizes subjects by individual accounting standards. In contrast, the POC was structured according to such matters as technical considerations, characteristics of financial information, accounting principles, measurement criteria and type of financial statements.

3) It has a specific accounting language, similar to IFRS. This led several new words to be introduced to the Portuguese accounting lexicon (e.g., recognition, derecognition, measurement, impairment).

4) It has new accounting concepts and measurement criteria (e.g. cash generating unit, recoverable amount, value in use, biological assets).

5) It increased the level of disclosure substantially.

Adoption of the SNC also changed regulations governing the functioning of the CNC and OTOC. The CNC became smaller. OTOC was elevated in status to $\operatorname{Order}^{6}$ of Official Accountants.

\section{Research method}

A qualitative research approach involving semi-structured interviews was used to acquire an in-depth understanding of the events leading to adoption of the SNC. This method is appropriate if, as here, the purpose is to develop a detailed and well-rounded understanding of a social process, social change, social organization or social meaning (Mason, 2002; Saunders et al., 2003). The interviews were conducted in Portuguese (the native language of all interviewees and interviewers). They were taped-recorded.

\footnotetext{
${ }^{6}$ OTOC was previously known as Câmara dos Técnicos Oficiais de Contas (CTOC - Chamber of Official Accountants) before the publication of the law establishing the SNC in 2009. "Order" is the highest social status of a profession in Portugal.
} 
Interviews were transcribed in Portuguese to avoid the possibility that idiomatic terms and particular meanings might be distorted. Interview transcripts were sent to respondents for them to correct any errors and misinterpretations. This procedure also provided interviewees with the opportunity to volunteer additional information and to summarize information. The process reinforced the accuracy of interview data. Translation of interview transcripts into English occurred after the interviewees had confirmed correctness.

Interviews were conducted at different points in time since the new accounting standards were prepared by the CNC in 2007 but were not applied by accountants until 2010. To elicit information at the political and economic level, two interviews were conducted with several members of the CNC. The first interview, in June 2008, was with the President of the CNC (interviewee A) and two other members of the Executive Commission (interviewees B and C). The second interview, in August 2008, was with the President of the Executive Commission responsible for coordinating the workgroups that developed the new accounting standards (interviewee D) and interviewee B (who also participated in the first interview). The specific purpose of these interviews was to determine the main reasons for developing the SNC; to understand how the signification, legitimation and domination structures enabled and constrained actions of the $\mathrm{CNC}$; and to identify the main institutional entrepreneurs who influenced the progress (and final content) of the SNC.

In July 2008, the representative of the CNC on the Accounting Regulatory Committee (ARC) of the European Commission (interviewee E) was interviewed. The ARC provides opinions on European Commission proposals to adopt (endorse) IFRS. It is composed of representatives from all member-states. The main purpose of the interview was to assess the degree of political influence on the functioning of the CNC and to evaluate how the SNC reflected changes in legitimation, signification and domination structures in the EU in previous years.

At the organizational field level, we interviewed the President of OTOC (interviewee F) in March 2011. Our objectives were to elicit understanding of the role of OTOC in establishing new operating practices that would provide the legitimating base for actions at the level of accountants; the implications of the SNC for the accounting profession; knowledge of how the legitimation and signification structures evolved due to the adoption of the SNC; and knowledge of how OTOC influenced the development of the SNC. In late 2012 and early 2013, we interviewed the President of 
the Order of Official Auditors (interviewee G), the representatives on the CNC of the Portuguese Confederation of Commerce and Services (interviewee H), Confederation of the Portuguese Farmers (interviewee I), and Portuguese Confederation of Manufacturing (interviewee $\mathrm{J}$ ), to clarify the influences exerted by the organizational field level on the political and economic level.

At the organizational level, interviews were conducted in March and April 2010 with four accountants who had SMEs as clients (interviewees $\mathrm{K}, \mathrm{L}, \mathrm{M}, \mathrm{N}$ ); and in December 2012 with another four accountants (interviewees O, P, Q, R). The purpose was to understand how accountants prepared to adopt the SNC; the implications of the new system for their legitimating and signification structures; the influence of isomorphic pressures in institutionalizing the new accounting practices; and to reveal how the SNC was being applied by accountants. The interviewees differed in terms of age, client turnover, main activity of clients, and whether or not they worked in professions other than accounting. Table 1 provides profiles of all interviewees.

\section{Insert Table 1 Here}

To address issues of data reliability and data validity we followed the methodological approach to interview conceptualization and operationalization proposed by Mason (2002), Quivy and Campenhoudt (2005) and Saunders et al. (2003). Information about the context of the interviewees' organizations was gathered in advance of interviews to enhance credibility and gain the confidence of interviewees. A list of interview topics was provided to participants in advance. This promoted validity and reliability by enabling interviewees to prepare the information being requested. During the interviews a neutral tone of voice was used. Long questions and theoretical concepts were avoided. The interviewees were given time to develop their responses. Whenever necessary, answers were read back to interviewees in summary form to test for correct understanding. A conscious effort was made not to allow the personal perspective of the interviewer to influence the responses of interviewees. To enhance data sensitivity, interview data were coded by the researchers using a coding scheme developed during the reading of the transcripts. A conceptual matrix was prepared to help summarize the main themes discussed by the interviewees.

In addition to data collected from interviews, other information was gathered from several other formal sources associated with the process of developing and implementing the SNC. Data were triangulated with proposals of political parties in the 
Portuguese Parliament (CDS-Partido Popular, 2010; Partido Comunista Português, 2009), minutes of ARC meetings, ${ }^{7}$ press releases (Ministry of Finance, 2005), government speeches (Minister of Finance, 2008; Secretary of State for Fiscal Affairs, 2008), official documents of the CNC (CNC, 2003; 2007) and official documents of the European Commission (European Commission, 2006; 2012). Relationships between themes raised in the interviews were established through re-reading data and matching those data with documentary information collected. The interviews and the documents were coded according to the themes being analysed.

\section{Results}

Our results highlight the evolution of three dimensions of contextual change (signification, legitimation, and domination) for each of the three levels of social context suggested by Dillard et al. (2004). They aid understanding of the relational dynamics flowing from the economic and political level (Section 5.1), to the organizational field level (Section 5.2), and to the organizational level (Section 5.3). At the political and economic level we identify the actors who can be regarded as institutional entrepreneurs: that is, who initiated divergent changes and who mobilized resources to implement these changes.

\subsection{Economic and political level: Changes in signification, legitimation and} domination structures

Analysis of the evolution of legitimation, signification and domination structures in the organizational field of accounting reveals that the rationale for accounting has changed during the past century. The development of stock exchanges, evolving patterns of investments, and increased scrutiny of financial statements in the second half of the 20th century, are some events that have connected accounting and economic decision-making (see Young, 2006). The financial statement user has been conceived commonly as a rational economic decision-maker who required value-relevant information, a reduced incidence of earnings management, and timely loss recognition adjustments (Barth et al., 2008). Additionally, in the period following the East Asian financial crisis of 1997-1998 financial capital was encouraged to assume a dominant position within world capitalism. Policies of financialization of national economies became common. Underlying neo-liberal models, based on the elimination of capital

\footnotetext{
${ }^{7}$ Available at: http://ec.europa.eu/internal_market/accounting/committees/arc_meetings_en.htm, accessed on 1 April, 2011.
} 
controls and the standardization of world financial markets, boosted a so-called 'new international financial architecture' (Arnold, 2012). This response to the East Asian crisis, led by the United States, promoted the spread of an Anglo-American style of capitalism based upon a weak financial governance regime, less-than-complete transparency, international financial standards, and market self-discipline. In this environment, IASB standards were enforced as a remedy for financial instability and as a pathway to economic development (Arnold, 2012).

Nonetheless, the collapse of Enron in 2001, and other major international accounting scandals in this period, raised doubts about the stability of accounting standards. These doubts were resolved partially through the shift from highly detailed rules-based United States accounting standards to more general principles-based accounting standards (Bhimani, 2008). The accounting representation schema evolved towards utility of financial information and to a principles-based approach. This allowed IASB standards to become an increasingly influential system of representation or signification - as more people accepted IASB standards as common knowledge and as the normal basis for doing accounting (Rodrigues and Craig, 2007). Thus, the IASB acquired a 'soft' form of power that enabled it to enforce a dominant logic (Suddaby et $a l ., 2007)$ that was supported by neo-liberal ideologies. This social, political and economic context within which the international accounting harmonization process evolved, defined structural boundaries for action in the accounting arena within the EU, member-states, professional associations, and individual organizations.

In 1995, the Commission of the European Communities report titled 'Accounting harmonization: a new strategy vis-à-vis international harmonization' (European Commission, 1995) acknowledged the inadequacy of European accounting directives in effecting accounting harmonization. It expressed also support for IASB standards. Thereafter, the EU increased funding of IASB activities. This reinforced the adequacy and importance of IASB standards within the EU. The resources allocated by the EU to IFRS also reinforced the signification structures associated with IASB standards within the EU (Dillard et al., 2004). These new signification structures validated the assumption that financial information which accorded with globally accepted accounting standards was superior and legitimate (Rodrigues and Craig, 2007).

Interviewee $\mathrm{E}$ (the $\mathrm{SNC}$ representative on the ARC) advised that: 
Over the past years the funding of the IASB has been widely discussed in meetings of the ARC. The EU has paid substantial amounts to the IASB, due to the adoption of IFRS by member-states.

The minutes of ARC meetings show that resource allocation to new structures prompted by IASB standards was, and still is, an important matter for the European Commission. Several ARC meetings included as a point of discussion: 'IASB Governance, European Financial Reporting Advisory Group enhancement and funding., ${ }^{8}$

Changes in signification structures were followed by a change of norms and values: that is, of legitimation structures in the EU. European accounting directives were modified to accord with IASB standards. In 2002, the European Commission's Regulation 1606/2002 required all EU-domiciled companies listed on stock exchanges within the EU to prepare their consolidated financial statements in accord with IFRS by 2005. This provided new legitimating grounds for action by member-states $\left(\mathrm{C}_{\mathrm{PE}}\right)$. In turn, this dynamic flowed to accounting regulations issued for unlisted companies by those member-states who had changed their national accounting system by adopting IFRS (or adapted IFRS). The change helped them to ameliorate the ensuing lack of comparability of financial information among national companies (listed versus unlisted companies). These regulatory changes enabled new concepts and ideas to be introduced in national accounting systems in accord with the new signification and legitimation structures in the EU.

In Portugal, political criteria were translated into a new accounting system by the CNC. This occurred at the political and economic level rather than at the organizational field level. ${ }^{9}$ Creation of the new accounting system began in 2002. In 2003, the CNC website published a projected accounting model (representing the probable future of the Portuguese accounting system) (CNC, 2003). The structure was similar to that of the SNC. Interviewee A noted that:

\footnotetext{
8 See http://ec.europa.eu/internal_market/accounting/committees/arc_meetings_en.htm, accessed on 1 April, 2011.

${ }^{9}$ Even though the new criteria in the accounting field (the SNC) were established at the political and economic level, new operating practices $\left(\mathrm{P}_{\mathrm{OF}}\right)$ had to occur at the organizational field level (as a result of the training provided by professional accounting associations).
} 
In 2003, the CNC considered the adoption of international accounting standards because the POC was becoming insufficient and several other European countries (such as Spain) were changing their national accounting laws to align with IFRS.

Interviewee B observed that:

After Regulation 1606/2002, the decision to move forward to IFRS was consensual among members of the $\mathrm{CNC}$, even though the existing differences between the POC and IASB standards demanded significant preparation efforts by Portuguese accountants. It did not make any sense to have significantly different accounting systems applied by listed and unlisted companies.

According to interviewee $\mathrm{J}$, the need for the Portuguese accounting system to evolve was highlighted by Regulation 1606/2002, the modernization of the European Accounting Directives, and the desire to reduce administrative costs.

Problems identified in an institutional field stimulate institutional change and entrepreneurial actions (Greenwood and Suddaby, 2006; Hardy and Maguire, 2008; Seo and Creed, 2002). Thus, prompted by Regulation 1606/2002, the CNC presented the SNC as a new institutional arrangement that would help reduce problems of financial statement comparability.

The composition of the CNC's Executive Committee (the main body responsible for developing regulatory changes to the Portuguese accounting system) reveals how its members were exposed to IFRS logic. The principal profession of eight of the thirteen members (62\%) was 'Official auditor'. Interviewee E noted that:

Several members of the executive committee have worked in multinational companies that report in accordance with IFRS. Others are official auditors of multinational companies, and of listed companies. One member represents the Portuguese stock exchange regulator (Comissão do Mercado de Valores Mobiliários [CMVM]). All these members are very familiar with IFRS and have supported their adoption. 
These members had been exposed to alternative practices and this helped to enable the entrepreneurial action of the CNC. IFRS were already part of their grounds for signification and legitimation because of the acceptance of IFRS by multinational companies, the audit profession and stock markets. Interviewee B observed that:

Members of OROC have always appreciated IASB standards. OROC is very supportive of IFRS. Even if it was his personal opinion, the President of OROC mentioned several times publicly that IFRS should be adopted by all types of companies.

Interviewee $\mathrm{G}$ (the President of OROC) affirmed this view:

The adoption of the SNC was very important for the audit profession. The POC was obsolete and had several gaps. We also felt that our opinion regarding the development of the SNC was supported at the CNC through the presence of several official auditors on the main bodies of the $\mathrm{CNC}$, including the future president of the CNC. He was a member of the Superior Council of OROC.

Change processes depend on the opportunity to access the political system and political allies (Lounsbury and Crumley, 2007; Rao and Giorgi, 2006). Additionally, some actors have positions that accord them legitimacy with respect to diverse stakeholders. These actors do not possess power. Instead, they occupy positions allowing them to exercise power over the field (Hardy and Maguire, 2008). Given the code-law features of the Portuguese accounting system, the support of the Portuguese Government was essential for the SNC to proceed. In 2005, the CNC project was strengthened by the appointment of a Minister of Finance who had been President of the Directing Board of the CMVM for five years before joining the Government in July, 2005. He had also been a former President of the Executive Commission (and the Regional European Committee) of the International Organization of Securities 
Commissions (IOSCO) for four years, and President of a group of experts of the Committee of European Securities Regulators.

According to interviewee E, 'claims of listed companies about the costs of maintaining a dual accounting system were an important factor in the decision to proceed with the SNC by the Ministry of Finance.' Indeed, the Minister of Finance played a significant role in developing and implementing the SNC. In December 2005, he met the Council of the CMVM. The Minister's embeddedness in the stock exchange field led him to support the interests of listed companies. After this meeting, a Ministry of Finance press release announced that it would study 'the possibility of the exclusive use of IFRS ... to avoid the necessity of keeping two sets of accounts by listed companies ... [and that it would create] a working group to adapt the company income tax code so that IFRS could be used by all companies' (Ministry of Finance, 2005: 1).

In 2006, the CNC began developing the SNC in its final form. However, the Portuguese Government exercised influence on the SNC's content by forcing the introduction of a specific standard for SMEs. This was something that was not envisaged in the initial SNC project (CNC, 2003). In early 2006, the CNC met with the Secretary of State for Fiscal Affairs to present the structure of the new accounting system. Interviewee D explained that at this meeting 'The Secretary gave explicit instructions to incorporate, in the new accounting model, a specific accounting standard for SMEs.'

Interviewee $\mathrm{G}$ explained that the NCRF-PE was suggested by the Portuguese Government because the political context of the EU was encouraging reductions in administrative costs. In 2006, a European Commission working document referred to 'unnecessary and disproportionate administrative costs severely hamper[ing] economic activity'; and it drew attention to the Commission's commitment 'to reducing these unnecessary burdens to the maximum extent possible' (European Commission, 2006: 2). ${ }^{10}$ According to interviewee G, 'The NCRF-PE had to be created so that the SNC could be implemented. The SNC and the NCRF-PE are a combined product.' Interviewees $\mathrm{H}$ and $\mathrm{J}$ corroborated this assessment.

The representative of the $\mathrm{CNC}$ on the ARC (interviewee E) confirmed that from 2006, the development of the new accounting system was monitored closely by the Secretary of State for Fiscal Affairs. In the context of the SNC, political influence was

${ }^{10}$ In 2012, the European Parliament and Council issued Directive 2012/6/EU (amending Council Directive 78/660/EEC) regarding the annual accounts of certain types of companies, with respect to micro-entities. 
evident also in the establishment of quantitative boundaries. These distinguished companies that were required to use all standards from those who were required to use only the SME standard.

In 2007, the CNC announced the SNC publicly. In the official document that presented the SNC project (CNC, 2007), the CNC sought to '[c]raft a vision for divergent change' (Battilana et al., 2009: 79). Rationales for institutional change by the CNC were constructed by explaining the international accounting harmonization process, the insufficiencies and disadvantages of the existing accounting system, and how the existing system had failed to accommodate the interests of all companies. ${ }^{11}$ The theorization of the SNC continued in April 2008, when the CNC began the 'due process' phase for approval of the SNC. The CNC presented the new accounting system for public evaluation in a public ceremony attended by the Minister of Finance and the Secretary of State for Fiscal Affairs. Both made speeches emphasizing the problems of the old system and the advantages of the SNC. The Minister of Finance (2008: 2) noted that the SNC model 'will be an additional vehicle to modernize our economy because our companies and economic agents will be better able to integrate into the new economic world context.' The Secretary of State for Fiscal Affairs (2008: 5) reinforced this by asserting that 'the new accounting strategy is appropriate in the actual context of internationalization, trade liberation and economic globalization ... the SNC is itself a source of competitiveness...'.

To avoid criticism that the SNC favored listed companies by imposing an accounting model that was inappropriate for the majority of Portuguese companies, the ministerial discourse also sought to resonate with the interests and needs of SMEs. The Minister of Finance (2008: 6) acknowledged the different characteristics of Portuguese companies. He stated that 'the SNC took into account their different financial information needs. These range from entities with listed securities, with increased demands, to micro-entities that only need a simplified system.' The Secretary of State for Fiscal Affairs (2008: 7) repeated this statement word-for-word in his speech, as well. This theorization process invoked the inefficiency of the POC and claimed advantages of the SNC to develop the perception that there were benefits for all actors in the accounting field, and to encourage actors to participate in the change process (Greenwood et al., 2002).

\footnotetext{
${ }^{11}$ The CNC considered the POC needed technical revision to incorporate a conceptual framework, and recognition and measurement criteria. The POC had been in force for 25 years and no longer responded well to contemporary requirements.
} 
However, the inclusion of the NCRF-PE in the SNC was not unanimous among members of the CNC. Interviews revealed that both OROC and the Confederation of Commerce and Services were against the inclusion of this standard because its simplicity risked limiting the SNC's effects. However, the Confederation of Farmers and the Confederation of Manufacturing interviewees agreed with this standard. According to interviewee I: 'Most agricultural businesses are small... so we have tried to make the CNC aware of the need for the NCRF-PE.' The representative of the Confederation of Manufacturing (interviewee J) acknowledged that the SME standard was important for the manufacturing sector due to the small size of many companies in that sector.

Since the SNC came into effect in January 2010, the limits under which companies are allowed to use the NCRF-PE have changed. Initially, decree-law 158/2009 (13 July) established that NCRF-PE could be used by companies that fell within two of the three following limits: total assets $€ 500,000$; total sales and other income $€ 1,000,000$; and number of employees 20. However, in December 2009 the Portuguese Communist Party submitted a proposal to amend this law by increasing these limits to $€ 1,500,000 / € 3,000,000 / 50$ respectively. The proposal explained that the limits of $€ 1,500,000 / € 3,000,000 / 50$ used in the Companies Law 'in practice, separates small companies from large companies' (Partido Comunista Português, 2009: 3). These limits are accepted widely in the Portuguese accounting field. This proposal was approved by Decree-Law 20/2010 (23 August), thereby allowing many more companies to use the NCRF-PE. ${ }^{12}$

Representatives of sector confederations (interviewees H, I and J) concurred with the changed limits, despite the fact they did not influence this change. The Presidents of OTOC (interviewee F) and OROC (interviewee G) revealed that they played an active role, in effected as institutional entrepreneurs, in changing the limits. OTOC sought to increase the number of companies required to use the NCRF-PE only, by increasing the limits. However, due to OROC's influence, the limits were increased only up to the point at which they triggered the legal requirement for official auditing. The President of OROC (interviewee $\mathrm{G}$ ) explained his rationale as follows:

This was a particular aspect about which OROC pressured the Government. It would be very complex for official auditors to use two sets of standards (the

\footnotetext{
${ }^{12}$ See http://debates.parlamento.pt/page.aspx?cid=r3.dar, accessed on 1 March, 2011.
} 
NCRF-PE and the 28 standards). As the new limits matched the limits of official audit, we had important productivity gains. This was because we only have to deal with the 28 standards [and not the NCRF-PE standard as well].

With respect to the domination perspective, it is important to recognize that the EU controls the allocation of significant funds to member-states. Thus, Portuguese Government decisions are constrained by choices taken by the EU. In turn, the CNC is resource-dependent on the Portuguese Government. This chain of power and domination reinforced the development of new legitimation and signification structures at a national level, consistent with $\mathrm{C}_{\mathrm{PE}}$ and the recursive aspect of the institutionalization process suggested by Dillard et al. (2004).

\subsection{Organizational field level: Changes in signification, legitimation and domination structures}

Generally, large Portuguese companies have their own accounting department or individual accountant. Usually, smaller companies are managed by owners and engage an external accountant. Because SMEs comprise the majority of companies in Portugal, most of the 31,000 official accountants registered to practice by OTOC have SMEs as clients. The President of OTOC (interviewee F) affirmed this, and the role of accountants, with respect to SMEs:

SMEs are the main business for accountants. SMEs do not have a structure to support management. Therefore, accountants should have a close relationship with business owners, based on trust and partnership. Accountants should be multifaceted and support business decisions of managers with useful information. To do so, they need a great knowledge of the business, its needs and growth perspectives.

Interviewee F disclosed that the Secretary of State for Fiscal Affairs had contacted him in 2008, when he was President of CTOC (OTOC's predecessor body until 2009) to ascertain CTOC's position regarding the SNC. Interviewee F saw this as an opportunity to develop the accounting profession and to raise its social standing. Because of the grounding of the SNC in a principles-based approach (as opposed to the rules-based 
approach of the POC), the SNC demanded a much deeper knowledge of the accounting environment by accountants. The President noted that the SNC:

... adds a new dimension to accounting: it encourages integration of the accountant with the reality he is accounting for, and with decisions of management. This results in much more active and conscious actions by accountants...

The SNC accorded with the signification and legitimation structure of the accounting profession by valuing the partnership between accounting and business management.

In the 2008 meeting between the Secretary of State for Fiscal Affairs and interviewee F [then President of CTOC], both were aware of the important role of this professional accounting body in providing the necessary supporting professional training to ensure the success of the SNC. Interviewee F argued that because adoption of a new accounting system posed so many challenges to the accounting profession, the social status of the profession should be raised from 'Chamber' to 'Order' - as it duly was. Interview $\mathrm{F}$ recognized that:

The SNC was an opportunity to elevate the status of the profession ... it required accountants to be better prepared and its expertise requirements ... gave more importance to the accounting profession.

The negotiation of concessions from the Government during the establishment of the SNC was enabled by the collaborative relationship that had developed between OTOC and the Government over several years, especially in connection with tax administration matters.

Nonetheless, the State had fundamental control of the resources available to professional accounting bodies such as OTOC. The State, through a legal requirement of the Ministry of Finance, required all companies to have their financial statements and tax declarations signed by an 'official' accountant. The 'official' designation implies 
compulsory membership of OTOC ${ }^{13}$ - and payments to OTOC for membership fees and professional training. This indirect resource dependence by OTOC on the Ministry of Finance made it unlikely that OTOC would oppose the SNC (domination perspective) especially as OTOC had been consulted about its official position when the SNC was almost finalised. Thus, even if OTOC objected to features of the SNC and preferred to adapt the old accounting system in preference to IFRS (as occurred in Spain and France), it would be very difficult to sustain such a position. In this context, OTOC strived to exact concessions from the Government to achieve the same status (of 'Order') of the audit profession. The Portuguese Government, who acted as a fundamental ally of the $\mathrm{CNC}$, employed this exchange strategy. The Government granted the status of Order to CTOC (hence it became OTOC) in exchange for support in implementing the SNC. This is characteristic of institutional entrepreneurs who negotiate the resources they possess to impose their new institutional project. However we should note the view of Hardy and Maguire (2008: 210) that:

... institutional entrepreneurs do not work single-handed; they engage with other members of the field. Institutional entrepreneurship therefore seems to be predominantly a collective process $[\ldots]$ to co-opt opponents rather than to confront them, thereby avoiding overt conflict and resistance.

OTOC fulfilled its part of the agreement by providing extensive professional training courses on IFRS and the SNC. The number of courses offered grew from 3 in 2007, to 5 in 2008, 26 in 2009, and 37 in $2010 .{ }^{14}$ An important factor was that the SNC accounting model implied a different accounting paradigm for the accounting profession - one that is principles-based. This paradigm required additional professional judgment, high levels of disclosure, separation between accounting and taxation rules, new terminology, and a new way of preparing accounting information. The mandatory nature of OTOC's professional training ensured it played a vital role in establishing new accounting practices and a new institutional logic.

\footnotetext{
${ }^{13}$ This requirement was first imposed by the Decree-Law 265/1995 (which created the Association of Official Accountants). This was later reinforced by Decree-law 452/1999 (5 November) which approved the Statutes of the Chamber of Official Accountants (see also Rodrigues, Gomes and Craig, 2003). This Decree-law was changed by Decree-law 310/2009 (26 October) which approved the Statutes of the Order of Official Accountants.
}

${ }^{14}$ See http://www.otoc.pt, accessed on 1 March, 2011. 
Other key players in the organizational field also supported the development of the SNC. OROC had supported adoption of the SNC since it was first mooted. However, according to the President of OROC (interviewee G):

\begin{abstract}
OROC has never organized any action to influence the evolution of the process. Nonetheless, the presence of OROC on the CNC, as well as other informal contacts OROC had with members of the Government, were used to express OROC's opinion. During the final stage of development of the SNC the relation between OROC and the Ministry of Finance was very good because the vice-president of OROC and the Minister had been colleagues at the University of Porto.
\end{abstract}

Interviewees $\mathrm{I}, \mathrm{H}$ and $\mathrm{J}$ stated that their sector confederations were also in favor of the development of the SNC.

In sum, new legitimating criteria $(\mathrm{COF})$ were supplied by the $\mathrm{CNC}$ at the political level. Then, operating practices $\left(\mathrm{P}_{\mathrm{OF}}\right)$ were disseminated by OTOC, OROC, other professional accounting associations, and sector confederations, through extensive training in the SNC. Nonetheless, interrelationships between the political and economic level and the organizational field level were important in establishing the final version of the SNC. During the due process phase in 2008, an OTOC team of experts reviewed the proposed version and suggested important changes. The President of OTOC explained that '... the accounting profession influenced the SNC and accounting regulation greatly, mainly through the document prepared by our working group. Almost all suggestions were accepted.'

Interviewee $\mathrm{G}$, at the time of his participation on OTOC's expert group, was not yet President of OROC. However his active membership with OTOC and OROC can explain that the review document proposed by both bodies bore many similarities, despite OROC's proposals being presented from an audit perspective. This added 'strength to the proposals' (interviewee G). Additionally, the representative of the Confederation of the Portuguese Farmers (interviewee I) confirmed that two important paragraphs in the accounting standard relating to Agriculture (regarding measurement issues) were included, as suggested by his confederation, during this stage.

Thus, during the due process phase, the documents issued by OTOC, OROC, other professional associations and sector confederations contained operating practices 
for the organizational field that influenced the organizational field criteria established by the $\mathrm{CNC}$ at the economic and political level.

\subsection{Organizational level: Changes in signification, legitimation and domination} structures

Institutionalization of the SNC at an organization level implies changing the signification framework and legitimating grounds to accord with the legitimating criteria or organizational field practices of higher levels of the social context (Dillard et al., 2004).

Four of the eight accountants interviewed had only small companies as clients (interviewees $\mathrm{L}, \mathrm{M}, \mathrm{N}$, and Q). The remaining accountants (interviewees $\mathrm{K}, \mathrm{O}, \mathrm{P}$ and $\mathrm{R}$ ) had small clients too, but they also had SMEs clients who exceeded the limits of the NCRF-PE. Accountants with only small clients chose to adopt the NCRF-PE standard for SMEs. The main reasons were that ' $\ldots$ it is simpler to work with' (interviewee M) and it is very similar to the requirements of POC, despite more information being required in the notes' (interviewee L). The accountants with the broader client list chose to apply the 28 standards to all of their clients.

At the organizational level, exclusive use of the NCRF-PE by accountants with only small clients limited the effects of the SNC, for two main reasons. The first reason was the conflict between adoption of the SNC and the needs and goals of these accountants. As result, accountants avoided a de facto application of the new accounting system (Oliver, 1991). Although the transition process involved high costs (especially for training and software), accountants were unable to increase their service fees commensurately because of general economic stringencies flowing at that time from the Global Financial Crisis of 2008. In addition, there was no broad social consensus among accountants concerning the merits of the new system to organizational decision-makers (Battilana et al., 2009; Greenwood et al., 2002; Tolbert and Zucker, 1996). All accountants who had only small clients regarded the adoption of the SNC as not worthwhile for SMEs. Interviewees $\mathrm{M}$ and $\mathrm{N}$ argued that the SNC was unnecessary and should not be applied by SMEs. Interviewee Q contended that 'The POC was serving needs perfectly.' Interviewee M explained that:

In the end [the SNC] is not worthwhile because our [small] clients companies do not use accounting information for decision-making and do not have a set 
of users of their financial statements. It takes a lot of work to adapt their accounting system.

The main users of financial statements of small firms are the State and banks. Consequently, the adoption of an accounting system that was oriented to a diversified set of users and required extensive disclosures, was considered to be inappropriate by these interviewees. Consistent with Oliver's (1992) view that de-institutionalization of practices usually involves functional pressures, Interviewees $\mathrm{M}$ and $\mathrm{N}$ (both accountants) claimed that revocation of POC and adoption of the SNC would render accounting information less reliable and less comparable - even though the resulting financial statements were likely to have more information in the notes. Interviewee $\mathrm{N}$ observed that:

The balance sheet and the income statement in the SNC have a much higher degree of summarization, so that all important information has to be in the notes. However, in small companies, the notes have very little information. Thus, in these companies, the quality of financial information will be worse than in the POC. ${ }^{15}$

Additionally, the inclusion of the NCRF-PE in the SNC enabled accountants with only small companies to use a simple version of IFRS, allowing them to preserve existing accounting practices. This was the second major reason for the limited effect of the adoption of the SNC at the organizational level. Because the operations of their clients were very simple, these accountants were not forced to use the set of 28 standards of the SNC. This allowed them to maintain the signification schema of the POC. Interviewees $\mathrm{M}$ and $\mathrm{Q}$ averred that in very small companies there were no significant differences between the two systems because accounting rules regarding current operations (such as sales, wages or purchase of goods and services) were identical. Interviewee $\mathrm{N}$ explained that 'The major difference is the chart of accounts. All the rest remains the same.' Interviewee L expanded on this by pointing to taxation implications:

${ }^{15}$ A seemingly obvious retort would be to suggest that a remedy would be to provide expanded notes. However Interviewee $\mathrm{N}$ is drawing attention to the traditional disinclination of Portuguese accountants to provide expansive notes to financial statements. 
Tax forms will demand thorough explanations of the options taken, which will increase our work. Thus, in small companies we will take the most basic and simple options. Accountants will limit their work to complying with tax obligations.

The main difficulties with the SNC that were identified by interviewees L, M, N and Q were specific accounting issues (e.g. deferred costs, accruals) whose treatment under the new regulation had to be re-assessed. Another important difficulty was in how to value tangible assets-in-use that had been totally depreciated in the POC accounting system. The solution of these difficulties involved professional judgment, full understanding of the new conceptual framework, and dealing with fair value. These were all vexing matters for these accountants - all of whom had maintained the old signification schema. Thus, in accounting firms with only small company clients, the signification and legitimating grounds did not reflect the new legitimating criteria and organizational field practices of higher levels of the social context.

With regard to the domination perspective, small accounting firms generally have one or two senior accountants who decide the norms and values that should prevail in organizational practices. Accordingly, the legitimating grounds and representational schemes of their firms reflected personal views of the SNC. For such accountants, the transition to the SNC was compulsory: it did not warrant new signification and legitimation structures. The allocation of resources complied merely with new legal requirements and OTOC's requirements for professional training.

As a group, accountants $\mathrm{K}, \mathrm{O}, \mathrm{P}$, and $\mathrm{R}$ behaved differently. They had several clients above the maximum limits that allowed application of the NCRF-PE. Thus, they adopted the 28 standards of the SNC for all client companies. This required them to change accounting procedures, thereby revealing different signification and legitimating grounds. This was confirmed by interviewees $\mathrm{P}$ and $\mathrm{K}$. According to interviewee $\mathrm{P}$, 'The SNC has proved to be an opportunity to rethink several accounting problems and to exchange ideas with colleagues.' Interviewee $\mathrm{K}$ reported that 'The SNC ... made employees discuss accounting and think carefully about certain issues, which was very useful.' These accountants embraced the new SNC accounting system because of several perceived advantages. Interviewee $\mathrm{O}$ regarded the SNC standards to be of 'higher quality, help the accountant more and generate more information compared to 
the POC.' Interviewee P contended that there was a 'huge change in terms of the quality of the information disclosed [and that] this quality depends heavily on the way the Notes are done.' This group of accountants also agreed that the SNC allowed more decision-making autonomy (freedom of choice) than the POC. Thus, it is easier for accountants to manipulate the accounting numbers' (interviewee P); and 'it is extremely subjective to find the assets' fair value if they are not in liquid markets' (interviewee R). Accordingly, the quality of the financial information was regarded now to be more dependent on the professional skills of the accountants.

Interviewees $\mathrm{K}$ and $\mathrm{O}$ had clients in the agriculture industry. They stressed that the SNC provided more appropriate regulation than the old accounting system (in which production animals were recognized as tangible assets irrespective of their specific characteristics). In this case, de-institutionalization of the former practices occurred because the POC was inadequate for some of their clients, particularly those in agriculture. Changes in the accounting law prohibited perpetuation of institutionalized practices of the POC (Oliver, 1992) forcing the accountants to apply the 28 standards. These combined events prompted new signification and legitimation structures that were supported by resource allocations beyond compulsory training (e.g., interviewee K hired a person to assist with conversion to the SNC, interviewee $\mathrm{P}$ paid for all employees to receive additional training in the requirements of the SNC).

Two different pressures operated at that level. The first was the pressure applied by the State through the imposition of the SNC and its associated enforcement measures (fines between $€ 500$ and $€ 1,500$ ). The State was also influential regarding the date companies converted to the SNC because of the fiscal obligations it imposed for 2010 (Value Added Tax declarations). The second pressure was exerted by clients.

In respect of his preparedness to adopt the SNC, interviewee K noted:

I have important responsibilities towards my clients, so I had to be prepared. Small companies did not notice the change of accounting system. But larger companies did. It was important that all went well for them to keep their trust in my work.

Even though most clients were unaware that a new accounting system had been adopted, all accountants felt they could not abandon clients' expectations of quality accounting services, regardless the accounting system in force. Interviewee $\mathrm{K}$ stated that 
'Even when our competitors have lower prices, clients do not change if the relationship with their accountant is good.'

All accountants interviewed agreed that their relationship with clients was stable and based on trust. However, to fulfill expectations, a limited application of the SNC was sufficient for some accountants. This is consistent with D'Aunno et al. 's (1991) argument that organizations rank new practices in terms of a hierarchy of unequally important institutional demands. Accordingly, Portuguese accountants changed their accounting practices to the extent necessary. They did so to maintain their legitimacy, in line with their assessment of the institutional demands placed on them by the State, banks and clients.

The intensive professional training all accountants were required to undertake legitimated a new cognitive base and promulgated new rules of professional behavior. For all accountants interviewed, talking with other colleagues (to clarify specific doubts during the adoption of the SNC) was an important part of their preparedness - it complemented their professional training.

\section{Discussion}

Our results validate the capacity of the Dillard et al. model to explain the topdown de-institutionalization of the POC and the adoption of the SNC. They confirm the usefulness of combining concepts of institutional entrepreneurship with the Dillard et al. model to explain the process of change in the Portuguese accounting system.

We reveal that the CNC, a central actor in its field, was an important institutional entrepreneur. The CNC initiated the SNC project and participated actively in its implementation by theorizing the process of change, harnessing political support, and mobilizing allies (Battilana et al., 2009; Rao and Giorgi, 2006). However, the CNC was not a dis-embedded 'heroic' institutional entrepreneur (a criticism made in recent studies of institutional entrepreneurship by Battilana et al., 2009; Lounsbury and Crumley, 2007; and Maguire et al., 2004). Instead, a confluence of events enabled the creation and development of the SNC and facilitated the entrepreneurial actions of the CNC.

At the PE level, IFRS gradually became the legitimating structure within the EU. On-going resource allocations reinforced these new accounting rules. However, we should recognize that when organizations are faced with identical contexts they may perceive them differently (Dillard et al., 2004). This is because organizations differ in 
terms of their strategies and abilities; signification, legitimating and domination structures; and the extent to which institutional practices are embedded within them. Indeed, responses of member-states to the change in signification, legitimation and domination structures in the EU were diverse: some maintained their accounting regulation but incorporated in them adapted IFRS standards (e.g. Spain and France); and others replaced their accounting system with a new set of accounting rules similar to IFRS (e.g., Portugal).

Regulatory changes in the EU, initiated after 1995, introduced new accounting criteria $\left(\mathrm{C}_{\mathrm{PE}}\right)$ based on IFRS. These provided the context for developing a new accounting system $\left(\mathrm{C}_{\mathrm{OF}}\right)$ in Portugal, consistent with Dillard et al. (2004). These regulatory changes disturbed the consensus within the accounting field in continental countries by increasing actors' awareness of an alternative accounting logic (Guerreiro et al., 2012; Seo and Creed, 2002). This important field condition triggered the entrepreneurial action of the CNC. The rise of IFRS in the EU highlighted the inefficiency of Portugal's accounting system, despite its long evolution. This motivated the CNC to solve this problem in the accounting field. It provided the CNC with the opportunity to construct rationales for change (Greenwood and Suddaby, 2006; Seo and Creed, 2002).

Several members of the Executive Committee of the CNC were aware of IFRS logic by virtue of their work experiences with multinational and listed companies. Embeddedness of actors in multiple fields provides alternative logics of action that affects the way actors interpret, evaluate and respond (Hardy and Maguire, 2008; Thornton and Ocasio, 2008). Since these actors were more aware of other models of action regarding accounting practices, they were less likely to prefer the prevailing institutional arrangement (the POC accounting system) (Boxenbaum and Battilana, 2005; Seo and Creed, 2002). Thus, they were more willing to support the development of an accounting system based on IFRS.

The embeddedness of several members of the Executive Committee in multiple fields enabled knowledge to be transmitted inside the professional network of official auditors - and, in turn, for this to be reflected in their position at the CNC. This helped develop awareness of the international accounting harmonization process - something that was fundamental to the formulation of the SNC.

Implementation of the change was fostered by claims by listed companies about the costs and difficulties of the dual accounting they were obliged to undertake. These 
claims were more prominent among official auditors who dealt with multinational companies and subsidiaries of listed companies. Eventually, as this problem became socially recognized, field-level negotiations ensued (Lounsbury and Crumley, 2007). The CNC found political support for the SNC from the Minister of Finance. As a former stock exchange regulator, the Minister was disposed to support the SNC. He was the ideal receptor of complaints by listed companies about the high costs of dual accounting. The minister's multiple embeddedness based on his work experience in financial markets (which embrace IFRS as the dominant institutional logic) guided his decision-making and it was very influential in enabling implementation of the new accounting system (based on IFRS) (Boxenbaum and Battilana, 2005). Accordingly, the Minister of Finance was an important ally of the CNC. The CNC also invoked the power and formal authority of the State to support the implementation of the SNC.

Thus, this study is consistent with several prior studies of institutional entrepreneurship (Battilana et al., 2009; Greenwood and Suddaby, 2006; Boxenbaum and Battilana, 2005) in confirming that actors' awareness of other fields, and their recourse to diverse institutional logics, are crucial in understanding the emergence of entrepreneurship.

It is unlikely that entrepreneurial outcomes will be embraced easily by actors who are committed to existing institutional arrangements (Garud et al., 2007). Consequently, implementation of divergent change involves mobilizing and motivating the social groups involved and creating 'a vision for divergent change' (Battilana et al., 2009) through a theorization process. This is even more critical in highly structured fields, where templates of appropriate organizational behavior are established (Greenwood et al., 2002). Change is often resisted because it threatens actors' sense of security and their established organizational privileges, increases the cost of information processing, and disrupts routines (DiMaggio, 1988; Powell, 1991). Both the CNC and the Portuguese Government were alert to the importance of attaining the consensus of interested parties about the new accounting standards in order to enhance future compliance levels. Accordingly, during 2007 and 2008, the CNC made the problems of the old accounting system explicit. The CNC theorized about the ways in which the SNC would resonate with the interests and problems of companies (Boxenbaum, 2006; Greenwood et al., 2002).

Furthermore, success of institutional change depends on the elements of continuity between the old and the new institutional project that are emphasized by 
institutional entrepreneurs; and on the ties they are able to create with their multiple audiences (Lounsbury and Crumley, 2007). Through the inclusion of a specific standard for SMEs in the SNC, the Government sought resonance with the interests and values of small companies. Nonetheless, the Government's choice was influenced also by political criteria of the EU that sought reductions in administrative costs.

This attempt to 'create a vision' about implementing the new accounting system was followed by the 'mobilization of allies' (Battilana et al., 2009; Greenwood et al., 2002; Lawrence et al., 2002). As is usual, entrepreneurial strategies employed by powerful actors operated through exchange mechanisms and the establishment of collaborative relations (Hardy and Maguire, 2008). The outcome was that other resources were mobilized to support implementation of the SNC: the Portuguese Government mobilized an important ally by cultivating an alliance with OTOC. This alliance made it easier for the main professional body (OTOC) to accept the new system, thereby helping to strengthen and legitimize adoption of the SNC. Because OTOC also possessed formal authority, this coalition also leveraged the importance of formal authority that was implicit in the process (DiMaggio and Powell, 1983). ${ }^{16}$

The recursive process of Dillard et al. (2004) incorporates changes upwards as a process in which taken-for-granted norms, values and beliefs are revised continually at all levels. Our findings reveal how the Portuguese Government responded to the need to reduce the impact of adopting a complex new accounting system. Pressures and complaints at the organizational field level encouraged the Portuguese Government to accept that more companies should be able to use simplified accounting systems; and that changes to the limits for use of the SME standard were necessary. OTOC and OROC played an active role in changing the relevant limits. This points to the important role that the interests of agents in the organizational field can play in establishing laws and regulations at the political and economic level.

Professional accounting associations were influential at the organizational field level (as Dillard et al., 2004, predicted). They were also influential primary agents at the political and economic level. Nonetheless, our study reveals that these interests were not homogeneous among organizational field actors. Accounting organizations and sector

\footnotetext{
${ }^{16}$ The Big-four companies were not influential in this process at the political level. Interviewee $\mathrm{C}$ noted that multinational audit companies do not influence the activity of accounting boards at a national level because they influence the IASB directly. Their influence at a higher level is consistent with Suddaby et al. 's (2007) argument that representation of the Big-four on the IASB board, and the importance of Bigfour donations to the IASB, means that these firms occupy a strategic structural position in shaping accounting regulation.
} 
confederations had contradictory opinions about the inclusion of the NCRF-PE in the SNC. This is consistent with recent theoretical views of the concept of organizational field that replace assumptions of uniformity, isomorphic actors, and a central coherent set of beliefs, with relational spaces where contending logics are a force for institutional change (Wooten and Hoffman, 2008). Regarding the inclusion of the NCRF-PE in the SNC, the influence of the organizational field at the political and economic level was not homogeneous because of the different interests and motivations of organizational field actors. Eventually, this weakened the influence of the organizational field at the political level, allowing the Portuguese Government to make decisions based primarily on the EU context.

The Dillard et al. model predicts a top-down institutionalization process in which operating practices $\left(\mathrm{P}_{\mathrm{OF}}\right)$ at the organizational field level are a function of organizational field criteria $\left(\mathrm{C}_{\mathrm{OF}}\right)$. The latter, in turn, are a function of societal level criteria $\left(\mathrm{C}_{\mathrm{PE}}\right)$. In the Portuguese case, organizational field practices were considered in establishing the new accounting system. This occurred through the membership on the CNC of OTOC, OROC and sector confederations, and participation of these bodies in due process proceedings. Operating practices of the organizational field influenced the document issued by OTOC, OROC and sector confederations. In turn, this influenced the organizational field criteria (the SNC) established at the economic and political level also. The Dillard et al. model does not address an earlier reversion of the cascading institutionalization process explicitly, even though the model allows such possibility.

Our results highlight that change processes are not initiated only at the organizational level by knowledgeable, reflexive agents and by conflicting criteria between societal and organizational values and society norms. Change can occur also in earlier stages when legitimate practices of agents, acting in the organizational field, need to be better accommodated in newly established legitimating criteria.

At the organizational field level, the SNC concurred with the prevailing representational schema of the accounting profession in the way ideas, interpretations and meanings are framed and the role they play in legitimating social action (Dillard et $a l ., 2004)$. The new accounting system accentuated the signification schema of OTOC by valuing the integration of accounting practices with business management practices. The SNC reinforced the professional criterion of 'usefulness of accounting information' and the professional expectation that there should be a partnership between accounting and business management. Additionally, the new accounting system strengthened the 
importance of the accounting profession by requiring a more conscientious practice of accounting - one involving a principles-based approach. These conditions favored the acceptance of the SNC by OTOC, the major accounting association.

Our analysis reveals that changes at the organizational field level were influenced by interests and agency; and that changes developed as a consequence of the dual forces of agency and structure (Beckert, 1999; Dillard et al., 2004). The President of OTOC believed that the interests and needs of the accounting profession were served poorly by the existing social status (Seo and Creed, 2002), especially when compared to the social status of the audit profession. Variation in the characteristics of different institutional arrangements within the accounting profession (Order versus Chamber) was an enabling condition for the expression of latent interests of agents (transformational agency) (Battilana et al., 2009; Seo and Creed, 2002). This enabled the President of OTOC to seek an elevation in the status of the accounting profession to 'Order'. This concession by the Government was compensated through the extensive professional training OTOC provided, so that legitimate operating practices would spread at the field level $\left(\mathrm{P}_{\mathrm{OF}}\right)$. The interests of OROC were also accommodated in the establishment of the SNC, mainly by the change made to the limits of the NCRF-PE.

At the organizational level, the SNC was adopted in two different ways. First, it was adopted by accountants with only small company clients who chose to use the NCRF-PE exclusively; and second, it was adopted by accountants with a heterogeneous set of clients (small, medium and large SMEs) who chose to adopt the 28 standards. For the first type, there has been a limited application of the SNC. The benefits of the SNC to the accounting profession that motivated the President of OTOC to embrace the new accounting system were not perceived as accruing to accounting firms with only small clients. Because of the client characteristics of these accounting firms (especially in using accounting mainly for tax purposes), the claimed advantages of the SNC were not experienced. Rather, the SNC was perceived to require excessive transition costs and an undue level of effort for a reduced number of financial statement users.

Organizational field practices $\left(\mathrm{P}_{\mathrm{OF}}\right)$ can be translated at the organizational level into working practices and be enacted subsequently at the intra-organizational level (Hopper and Major, 2007). If these practices reinforce interests and beliefs of agents at this level, they are institutionalized. However, if contradictions occur, resistance to the institutionalization of the imposed practice is expected (and organizations exert pressure to change eventually) (Cruz et al., 2009). In the present case, at the organizational level, 
accounting firms with only small clients experienced two important institutional contradictions. There was an increase in the efficiency gap between the structure being adopted and their routines and practices grounded in the old accounting system. Additionally, there was a misalignment between features of the SNC (that ultimately reflected the goals and needs of multinational corporations and capital markets) and the interests and needs of the clients of these accounting firms. Even though these accountants applied the specific standard for SMEs, they were conscious of the institutional conditions that led to adoption of the new accounting system. Indeed, the increase in the initial application limits reveals how Portuguese companies were able to change the legitimacy criteria being imposed on them (consistent with Seo and Creed, 2002). These contradictions delayed enactment of the imposed practices and hindered de facto application of the new rules.

Resistance to new accounting rules and routines can be manifest in ceremonial use of accounting (Burns and Scapens, 2000). As a result, loose coupling of accounting neutralizes the impact of accounting change and leads to institutional stability (NorAziah and Scapens, 2007). The change in the chart of accounts was one of the most important changes for these accountants. By keeping existing arrangements separate, independent and unaffected by the SNC (that is, loose coupled), actual operations were unaffected by the implementation of accounting change. Thus, a degree of stability was maintained.

The fact that accountants with a heterogeneous client list responded differently reveals that the 28 standards of the SNC were capable of being well accepted when institutional contradictions are smaller - and when accountants share a view of the accounting profession similar to that of the President of OTOC. At the organizational level, these explanations are consistent with a conceptualization of organizational behavior that addresses internal organizational dynamics and embraces translation of new practices (Hopper and Major, 2007). Resistance can arise when the interests and needs of agents are contradicted by imposed practices. When they are not contradicted, institutionalization occurs. The accountants with heterogeneous client lists are now operating in a new societal context where legitimating structures require implementation of a principles-based accounting system and a deeper application of the concept of utility of financial information. These accountants acknowledged the need for accounting to be timelier, value-relevant and less conservative. They regarded the adoption of the SNC as an opportunity to rethink important accounting concepts. 
Adoption implied changing their signification schema and legitimating grounds. Such conceptualization is particularly useful in a context of adopting compulsory practice. It provides better understanding of organizational behavior than the two-stage diffusion process (innovators versus late adopters) described by Dillard et al. (2004).

\section{Conclusions}

Examination of the implementation of a new IFRS-based accounting system in a code-law country using the Dillard et al. (2004) model of institutional change and institutional entrepreneurship theory has revealed how the process of accounting change was enabled by the actions of multiple actors coalescing to support an institutional project. The CNC's entrepreneurial actions fostered the implementation of the SNC in a fashion that was generally consistent with the Dillard et al. (2004) model.

The results yield clarifying and expanded explanations of the Dillard et al. model, particularly in respect of how and why (entrepreneurial) actors engage in reflexive, knowledgeable human action within existing structures. They reveal the capacity of agents at the organizational field level to counteract the institutionalization process before it reaches the organizational level.

This examination of how the Portuguese accounting change process was enacted at the political and economic level reveals that regulatory changes within the EU disrupted professional consensus on code-law traditions. When allied with the embeddedness of important actors in multiple fields, this enabled the CNC to act as an institutional entrepreneur. Consciousness of alternative logics of action made the dominance of existing institutional arrangements no longer an inevitability. However, the creation of a new institutional arrangement needed to resonate with existing interests and with societal belief systems in order to mobilize resources and support (Seo and Creed, 2002). Institutional entrepreneurs used their political and social skills to promote collaborative relations (for example, between the $\mathrm{CNC}$ and the Portuguese Government and between the Portuguese Government and OTOC) to induce actors in the organizational field to co-operate with the change process. This is consistent with the view that 'institutional entrepreneurship seems to be predominantly a collective process' (Hardy and Maguire, 2008: 209). Nonetheless, social, economic and political criteria set the parameters for establishing the organizational field criteria and the limits within which institutional entrepreneurship occurred (Battilana et al., 2009; Dillard et al., 2004; Boxenbaum and Battilana, 2005). 
We have highlighted two ways whereby accounting organizations and sector confederations can be primary agents at the political and economic level: first, through their influence on the content of accounting regulation during the due process phase; and second, through the establishment of quantitative limits for the application of SME standards.

Inversion of the cascading institutional process is not necessarily a consequence of changes motivated by agents at the organizational level, as described explicitly by Dillard et al. (2004). Accordingly, in the 'due process' phase of establishing accounting standards, operating practices that are considered legitimate at the organizational field level are present in the positions taken by accounting organizations and other organized parties. They thereby influence regulations enacted at the political and economic level.

Additionally, in the accounting standard-setting context, the influential role of some actors at different levels occurs because of their involvement in all three levels of the Dillard et al. model. Accountants and accounting firms (the organizational level) are represented by OTOC (at the organizational field level), and this organization has representatives at the $\mathrm{CNC}$ (political level). This model of representativeness occurs in most countries in the accounting field, facilitating the inter-level dynamics proposed by Dillard et al. (2004), and explaining why pressures can move upwards and downwards in the societal system. Consequently, the expanded explanations we offer of the Dillard et al. model at the organizational field level reinforce the applicability of that model in the accounting domain.

Finally, we confirm that institutional influence at the organizational field level can spread in all directions (including upwards) through pressures on legislators. The actions of OTOC and OROC illustrate how their interests were accommodated by the change to the limits of application of the SME standard that were established at the political and economic level.

At the organizational level, accountants attempted to combine old representational schema with new legitimating criteria to resolve clashes between their interests and their needs. The loose coupled application of the Portuguese SME accounting standard confirmed that it was perceived to be easier to change accounting standards than to change the representational schemas accountants used to frame organizational reality.

Our results complement previous analyses (using institutional lenses) of the adoption of IFRS by nation states (Irvine, 2008; Mir and Rahaman, 2005). We reveal that institutionalization of new accounting practices depends on factors other than a 
coordinated structure that accommodates interests of the parties involved or that adapts IFRS to the needs of different users. Institutionalization of the change process initiated at the political level by the Portuguese accounting standards setting body involved taking advantage of political opportunity, mobilizing important allies, negotiating social positions, and accommodating the interests of major protagonists in the accounting field. Additionally, accounting concepts transferred from the previous system prevailed among accountants with only small clients - they adopted the SME standard. It was easier for them to change accounting standards than to change the signification schemas of accountants who framed the organizational reality they accounted for. The full adoption of the SNC standards favored tight coupling and de facto application of principles-based accounting standards (consistent with the purposes of the SNC) - as well as changing signification and legitimation structures at the organizational level. Because small companies usually do not have their own accountant, the SME standard helped small accounting firms make the transition to IFRS easily. Full adoption of IFRS by all companies, and by all accountants, would have demanded a greater preparation effort during the transition period. However, this would have facilitated changes in signification and legitimation structures at the organizational level and more consistent adoption of these standards.

We are wary not to generalize findings based on a single case. However, when it is possible to relate research results to theoretical propositions (as here) those results have a broader significance (Moll et al., 2006). Because institutionalization is a longitudinal process (Scott, 2001), assimilation of the new accounting standards will take time. Further qualitative studies could improve understanding of the institutionalization process of the SNC by analyzing the adoption of the 28 standards by large companies (which were not included in this study) or by exploring how legitimation and signification structures of small accounting firms have evolved. Additionally, further studies should seek to understand whether institutional entrepreneurship ends once new accounting systems are established or whether entrepreneurial actions are undertaken afterwards. Also, the approach used here can be replicated to study the institutionalization of new accounting systems in other countries. This would allow comparisons of institutional dynamics among different nation states. Such studies would help refine the Dillard et al. model further by providing a deeper understanding of the processes that articulate criteria and practices over the three levels of a variety of societal systems. 


\section{Archival sources}

ARC, Accounting Regulatory Committee. Minutes of ARC Meettings. http://ec.europa.eu/internal_market/accounting/committees/arc_meetings_en.ht $\mathrm{m}$

Cds-Partido Popular, CDS (2010) Grupo Parlamentar: Projecto de Lei n. ${ }^{\circ}$ 200XI/1 ${ }^{\text {a }}$ http://www.parlamento.pt/ActividadeParlamentar/Paginas/DetalheIniciativa.asp $\mathrm{x} ? \mathrm{ID}=35173$.

CNC, Comissão de Normalização Contabilística (2003) Draft with the guidelines for a new model of accounting standardization. Lisbon: CNC, http://www.cnc.minfinancas.pt/Documentos/NCN_LO_CE_AprovadoCG.pdf.

CNC, Comissão de Normalização Contabilística (2007) Draft with the guidelines for a new model of accounting standardization. Lisbon: CNC, http://www.cnc.minfinancas.pt/Documentos/NCN_LO_CE_AprovadoCG.pdf.

European Commission (1995) Accounting harmonisation: A new strategy vis-à-vis international harmonisation. COM 95 (508). http://ec.europa.eu/internal_ market/accounting/docs/com-95-508/com-95-508_en.pdf.

European Commission (2006) Commission working document - Measuring administrative costs and reducing administrative burdens in the European Union. COM (2006) 691 final. http://eur-lex.europa.eu/LexUriServ/ LexUriServ.do?uri=COM:2006:0691:FIN:EN:PDF.

European Parliament and Council (2012) Directive 2012/6/EU amending Council Directive 78/660/EEC on the annual accounts of certain types of companies as regards micro-entities of 14 March. Oficial Journal L81/3. http://eurlex.europa.eu/LexUriServ/LexUriServ.do?uri=OJ:L:2012:081:0003:0006:EN:P DF

INE, Instituto Nacional de Estatística (2008) Portugal Statistical Yearbook - 2007. https://www.google.pt/url? $s a=t \& r c t=j \& q=\& e s r c=s \&$ source $=w e b \& c d=3 \& v e d=$ OCEUQFjAC\&url=http\%3A\%2F\%2Fwww.ine.pt\%2Fngt_server\%2Fattachfileu .jsp\%3Flook_parentBoui\%3D53889897\%26att_display\%3Dn\%26att_download $\% 3 D y \& e i=u Z V J U b P u N I L C 7 A b d 0 Y H Y C A \& u s g=A F Q j C N F K s K U l I M x F t 9 I y e j k$ D0y6iQ2-FJA\&sig2 =_I_tPcqWprgL9JDLJB6ow\&bvm=bv.44011176,d.ZGU

Minister of Finance, T.S. (2008) Speech by the Minister of State and Finance at the presentation for public hearing of the new Accounting Standardisation System. http://www.min-financas.pt/discursos/int_MF_20080416.pdf.

Ministry of Finance, P.A. (2005) Minister of Finance meets with the National Securities Market. Press release - 15 December 2005. http://www.minfinancas.pt/comunicados/051213.asp.

Partido Comunista Português, PCP (2009) Grupo Parlamentar: Projecto de Lei n. ${ }^{\circ}$ 87/XI-1. ${ }^{a}$ Iniciativa. http://www.parlamento.pt/ActividadeParlamentar/Paginas /DetalheIniciativa.aspx?BID=34949

Secretary of State for Fiscal Affairs, L.B. (2008) Speech by the Secretary of State for Fiscal Affairs at the presentation for public hearing of the new Accounting Standardisation System. http://www.min-financas.pt/discursos/int_MF_ 20080416.pdf.

\section{References}


Alp, A. and Ustundag, S. (2009) Financial reporting transformation: The experience of Turkey, Critical Perspectives on Accounting, 20(5), pp. 680-699.

Arnold, P.J. (2012) The political economy of financial harmonization: The East Asian financial crisis and the rise of international accounting standards, Accounting, Organizations and Society, 37(6), pp. 361-381.

Battilana, J., Leca, B. and Boxenbaum, E. (2009) How actors change institutions: Towards a theory of institutional entrepreneurship, The Academy of Management Annals, 3(1), pp. 65-107.

Beckert, J. (1999) Agency, entrepreneurs, and institutional change. The role of strategic choice and institutionalized practices in organizations, Organization Studies, 20(5), pp. 777-799.

Bhimani, A. (2008) The role of a crisis in reshaping the role of accounting, Journal of Accounting and Public Policy, 27(6), pp. 444-454.

Boxenbaum, E. (2006) Lost in translation. The making of Danish diversity management, American Behavioral Scientist, 49(7), pp. 939-948.

Boxenbaum, E. and Battilana, J. (2005) Importation as innovation: Transposing managerial practices across fields, Strategic Organization, 3(4), pp. 355-383.

Burns, J. and Scapens, R.W. (2000) Conceptualizing management accounting change: An institutional framework, Management Accounting Research, 11(1), pp. 3-25.

Cruz, I., Major, M. and Scapens, R.W. (2009) Institutionalization and practice variation in the management control of a global/local setting, Accounting, Auditing \& Accountability Journal, 22(1), pp. 91-117.

Cuijpers, R. and Buijink, W. (2005) Voluntary adoption of non-local GAAP in the European Union: A study of determinants and consequences, European Accounting Review, 14(3), pp. 487-524.

D'aunno, T., Sutton, R.I. and Price, R.H. (1991) Isomorphism and external support in conflicting institutional environments: A study of drug abuse treatment units, Academy of Management Journal, 34(3), pp. 636-661.

Dillard, J.F., Rigsby, J.T. and Goodman, C. (2004) The making and remaking of organization context: Duality and the institutionalization process, Accounting, Auditing \& Accountability Journal, 17(4), pp. 506-542.

Dimaggio, P.J. (1988) 'Interest and agency in institutional theory', in Zucker, L. J. (Ed.), Institutional Patterns and Organizations. Culture and Environment, pp. 3-21 (Cambridge: Ballinger).

Dimaggio, P.J. and Powell, W.W. (1983) The iron cage revisited: Institutional isomorphism and collective rationality in organizational fields, American Sociological Review, 48(2), pp. 147-160.

Dumontier, P. and Raffournier, B. (1998) Why firms comply voluntary with IAS: An empirical analysis with Swiss data, Journal of International Financial Management and Accounting, 9(3), pp. 216-245.

Euronext (2010) Stocks directory \& quotes- price list. (Lisbon: Euronext).

Ferreira, L., García Lara, J. and Gonçalves, T. (2007) Accounting Conservatism in Portugal: Similarities and Differences Facing Germany and the United Kingdom, Revista Administração Contemporânea, 11(2), pp. 163-188.

Ferreira, L.F. (1998) 'Portugal', in Alexander, D. and Archer, S. (Eds.) European Accounting Guide, pp. 788-841 (London: Harcourt Brace).

Fontes, M.A., Rodrigues, L.L. and Craig, R. (2005) Measuring the convergence of national accounting standards with International Financial Reporting Standards, Accounting Forum, 29(4), pp. 415-436. 
Francis, J.R., Khurana, I.K., Martin, X. and Pereira, R. (2008) The role of firm-specific incentives and country factors in explaining voluntary IAS adoptions: Evidence from private firms, European Accounting Review, 17(2), pp. 331-360.

Garud, R., Hardy, C. and Maguire, S. (2007) Institutional entrepreneurship as embedded agency: An introduction to the special issue, Organizations Studies, 28, pp. 957969.

Giddens, A. (1976) New Rules of Sociological Method. (London: Hutchinson).

Giddens, A. (1979) Central Problems in Social Theory: Action, Structure and Contradiction in Social Analysis. (Berkeley, CA: University of California Press).

Giddens, A. (1984) The Constitution of Society: Outline of the Theory of Structuration. (Berkeley, CA: University of California Press).

Greenwood, R., Oliver, C., Sahlin, K. and Suddaby, R. (2008) 'Introduction', in Greenwood, R., Oliver, C., Suddaby, R. and Sahlin, K. (Eds.) The Sage Handbook of Organizational Institutionalism, pp. 1-46 (Thousand Oaks, CA: Sage).

Greenwood, R. and Suddaby, R. (2006) Institutional entrepreneurship in mature fields: The big five accounting firms, Academy of Management Journal, 49(1), pp. 2748.

Greenwood, R., Suddaby, R. and Hinings, C.R. (2002) Theorizing change: The role of professional associations in the transformation of institutionalized fields, Academy of Management Journal, 45(1), pp. 58-80.

Guerreiro, M.S., Rodrigues, L.L. and Russell, C. (2012) Voluntary adoption of International Financial Reporting Standards by large unlisted companies in Portugal - Institutional logics and strategic responses, Accounting, Organizations and Society, 37(7), pp. 482-499.

Hardy, C. and Maguire, S. (2008) 'Institutional entrepreneurship', in Greenwood, R., Oliver, C., Suddaby, R. and Sahlin, K. (Eds.) The Sage Handbook of Organizational Institutionalism, pp. 198-217 (Thousand Oaks, CA: Sage).

Hopper, T. and Major, M. (2007) Extending institutional analysis through theoretical triangulation: Regulation and activity-based costing in Portuguese telecommunications, European Accounting Review, 16(1), pp. 59-97.

Irvine, H. (2008) The global institutionalization of financial reporting: The case of the United Arab Emirates, Accounting Forum, 32(2), pp. 125-142.

Lawrence, T.B., Hardy, C. and Phillips, N. (2002) Institutional effects of interorganizational collaboration: The emergence of proto-institutions, Academy of Management Journal, 45(1), pp. 281-290.

Lockett, A., Currie, G., Waring, J., Finn, R. and Martin, G. (2012) The role of institutional entrepreneurs in reforming healthcare, Social Science \& Medicine, 74(3), pp. 356-363.

Lounsbury, M. and Crumley, E.T. (2007) New practice creation: An institutional perspective on innovation, Organization Studies, 28(7), pp. 993-1012.

Maguire, S., Hardy, C. and Lawrence, T.B. (2004) Institutional entrepreneurship in emerging fields: HIV/AIDS treatment advocacy in canada, The Academy of Management Journal, 47(5), pp. 657-679.

Mason, J. (2002) Qualitative Researching. (London: Sage).

Meyer, J.W. and Rowan, B. (1977) Institutionalized organizations: Formal structure as myth and ceremony, American Journal of Sociology, 83(2), pp. 340-363.

Mir, M.Z. and Rahaman, A.S. (2005) The adoption of international accounting standards in Bangladesh: An exploration of rationale and process, Accounting, Auditing \& Accountability Journal, 18(6), pp. 816-841. 
Moll, J., Major, M. and Hoque, Z. (2006) 'The qualitative research tradition', in Hoque, Z. (Ed.), Methodological Issues in Accounting Research: Theories and Methods, pp. 375-398 (London: Spiramus).

Mueller, G., Gernon, H. and Meek, G. (1997) Accounting: An International Perspective. (Boston, MA: Irwin).

Nobes, C. and Parker, R. (2004) Comparative International Accounting. (London: Prentice Hall).

Nor-Aziah, A.K. and Scapens, R.W. (2007) Corporatisation and accounting change: The role of accounting and accountants in a Malaysian public utility, Management Accounting Research, 18(2), pp. 209-247.

Oliver, C. (1991) Strategic responses to institutional processes, Academy of Management Review, 16(1), pp. 145-179.

Oliver, C. (1992) The antecedents of deinstitutionalization, Organization Studies, 13(4), pp. 563-588.

Powell, W.W. (1991) 'Expanding the scope of institutional analysis', in Powell, W. W. and Dimaggio, P. J. (Eds.) The New Institutionalism in Organizational Analysis, pp. 183-203 (Chicago, IL: University of Chicago Press).

Quagli, A. and Paoloni, P. (2012) How is the IFRS for SME accepted in the European context? An analysis of the homogeneity among European countries, users and preparers in the European commission questionnaire, Advances in Accounting, 28(1), pp. 147-156.

Quivy, R. and Campenhoudt, L.V. (2005) Manual de investigação em ciências sociais. (Lisboa: Gradiva).

Rao, H. and Giorgi, S. (2006) Code breaking: How entrepreneurs exploit cultural logics to generate institutional change, Research in Organizational Behavior, 27(0), pp. 269-304.

Rodrigues, L.L. and Craig, R. (2007) Assessing international accounting harmonization using Hegelian dialectic, isomorphism and Foucault, Critical Perspectives on Accounting, 18(6), pp. 739-757.

Saunders, M., Lewis, P. and Thornhill, A. (2003) Research Methods for Business Students. (Essex: Pearson Education).

Schutte, D. and Buys, P.W. (2011) Cultural considerations and the implementation of IFRS: A focus on small and medium entities, Journal of Social Sciences, 26(1), pp. 19-27.

Scott, W.R. (2001) Institutions and Organizations. (Thousand Oaks, CA: Sage).

Seo, M.G. and Creed, W.E.D. (2002) Institutional contradictions, praxis, and institutional change: A dialectical perspective, Academy of Management Review, 27(2), pp. 222-247.

Suddaby, R., Cooper, D.J. and Greenwood, R. (2007) Transnational regulation of professional services: Governance dynamics of field level organizational change, Accounting, Organizations and Society, 32, pp. 333-362.

Thornton, P.H. and Ocasio, W. (2008) 'Institutional Logics', in Greenwood, R., Oliver, C., Suddaby, R. and Sahlin, K. (Eds.) The Sage Handbook of Organizational Institutionalism, pp. 99-129 (Thousand Oaks, CA: Sage).

Tolbert, P.S. and Zucker, L.G. (1996) 'The institutionalization of institutional theory', in Clegg, S. R., Hardy, C. and Nord, W. R. (Eds.) The Sage Handbook of Organizations Studies, pp. 175-190 (Thousand Oaks, CA: Sage).

Tsamenyi, M., Cullen, J. and González, J.M.G. (2006) Changes in accounting and financial information system in a Spanish electricity company: A new institutional theory analysis, Management Accounting Research, 17(4), pp. 409432. 
Weber, M. (1968) Economy and Society: An Outline of Interpretive Sociology. (New York, NY: Bedminster).

Wooten, M. and Hoffman, A.J. (2008) 'Organizational fields: Past, present and future', in Greenwood, R., Oliver, C., Suddaby, R. and Sahlin, K. (Eds.) The Sage Handbook of Organizational Institutionalism, pp. 596-623 (Thousand Oaks, CA: Sage). 
Table 1. Interviewee Details

\begin{tabular}{|c|c|c|}
\hline Position & Interviewee & $\begin{array}{l}\text { Duration } \\
\text { (minutes) }\end{array}$ \\
\hline President, CNC & A & 90 \\
\hline Member of the Executive Commission, CNC & $\mathrm{B}$ & 90 \\
\hline Member of the Executive Commission, CNC & $\mathrm{C}$ & 90 \\
\hline President of the Executive Commission, CNC & $\mathrm{D}$ & 90 \\
\hline Representative of CNC on the ARC & $\mathrm{E}$ & 60 \\
\hline President, OTOC & $\mathrm{F}$ & 120 \\
\hline President, OROC & G & 90 \\
\hline Representative of the Confederation of Commerce and Services of Portugal & $\mathrm{H}$ & 45 \\
\hline Representative of the Confederation of Portuguese Farmers & I & 90 \\
\hline Representative of the Confederation of Manufacturing of Portugal & $\mathrm{J}$ & 45 \\
\hline $\begin{array}{l}\text { Partner of an accounting firm. } 80 \text { clients (turnover }<€ 30,000,000) \text { in all sectors. } \\
\text { Some clients are in agriculture, but most are in the commercial sector. A } \\
\text { teacher in higher education. Age } 49 .\end{array}$ & $\mathrm{K}$ & 45 \\
\hline $\begin{array}{l}\text { Partner of an accounting firm. } 22 \text { clients (turnover }<€ 500,000 \text { ) in the services } \\
\text { sector, except for one client in the construction sector. Age } 36 \text {. }\end{array}$ & $\mathrm{L}$ & 45 \\
\hline $\begin{array}{l}\text { Partner of an accounting firm. } 40 \text { clients (turnover }<€ 300,000 \text { ) in the textile and } \\
\text { services industries. A trainee in a firm of official auditors. Age } 34 .\end{array}$ & M & 45 \\
\hline $\begin{array}{l}\text { Partner of an accounting firm. } 38 \text { clients (turnover }<€ 1,000,000 \text { ) in the services } \\
\text { sector exclusively. Age } 68 .\end{array}$ & $\mathrm{N}$ & 45 \\
\hline $\begin{array}{l}\text { Partner of an accounting firm. } 70 \text { clients (turnover }<€ 10,000,000 \text { ) in the textile, } \\
\text { agriculture, commerce and services industries. Age } 64 .\end{array}$ & $\mathrm{O}$ & 60 \\
\hline $\begin{array}{l}\text { Partner of an accounting firm. } 80 \text { clients (turnover }<€ 20,000,000 \text { ) in the textile, } \\
\text { footwear, hotels, culture sectors. Age } 37 .\end{array}$ & $\mathrm{P}$ & 45 \\
\hline $\begin{array}{l}\text { Accountant of a SME trading in construction materials (turnover } € 2,000,000 \text { ). Age } \\
57 .\end{array}$ & Q & 60 \\
\hline $\begin{array}{l}\text { Accountant of several SMEs. } 6 \text { clients (turnover }<€ 15,000,000 \text { ) in the textile, food } \\
\text { and stationery commerce. Age } 72 \text {. }\end{array}$ & $\mathrm{R}$ & 45 \\
\hline Total & 18 & \\
\hline
\end{tabular}

